Ирена Пантић ${ }^{*}$

https://doi.org/10.18485/zivjez.2018.38.1.11

ОШ „Димитрије Туцовић“

Краљево

\title{
ПРИМЕР ДОБРЕ НАСТАВНЕ ПРАКСЕ - НАСТАВА ЕНГЛЕСКОГ ЈЕЗИКА ПРИМЕНОМ CLIL МЕТОДЕ
}

Циљ овог рада јесте да представи један од начина извођења часа енглеског језика применом CLIL методе. Оваквим, прилично иновативним, интегрисаним учењем језика и садржаја повећава се мотивисаност ученика, побољшава разумевање и усвајање нових појмова на циљном језику. Поред тога, CLIL настава је одличан увод у билингвалну наставу, која је симбол модерног и перспективног образовања. Овде се енглески језик користи као алат за усвајање математичких термина, а не као наставни предмет сам по себи. Час је лако применљив у школској пракси и у фукнцији је међупредметног повезивања. Час је реализован у јануару 2018. године у одељењу VI разреда Основне школе „Димитрије Туцовић“ у Краљеву.

\begin{tabular}{|l|l|}
\hline \multicolumn{2}{|c|}{ Методичка припрема за извођење часа } \\
\hline Наставна тема & Science Matters \\
\hline $\begin{array}{l}\text { Редни број } \\
\text { наставне } \\
\text { јединице за } \\
\text { тему }\end{array}$ & 4 \\
\hline $\begin{array}{l}\text { Редни број часа } \\
\text { за годину }\end{array}$ & 35 \\
\hline $\begin{array}{l}\text { Наставна } \\
\text { јединица }\end{array}$ & Маths Маtters \\
\hline Тип часа & систематизација \\
\hline $\begin{array}{l}\text { Општи циљеви } \\
\text { и задаци часа }\end{array}$ & $\begin{array}{l}\text { Language focus - усвајање математичких термина на ен- } \\
\text { глеском језику; подстицање ученика за користе страни је- } \\
\text { зик (енглески) не само за комуникацију већ и за учење на } \\
\text { њему; интегрисање језика са рецептивним и продуктив- } \\
\text { ним језичким вештинама; персонализација наставе; }\end{array}$ \\
\hline
\end{tabular}

*_irenapantic01@gmail.com 
Ирена Пантић

\begin{tabular}{|c|c|}
\hline $\begin{array}{l}\text { Образовни } \\
\text { циљеви }\end{array}$ & $\begin{array}{l}\text { повећање знања, вештина и разумевања који су у вези са } \\
\text { специфичним елементима језика; богаћењеактивног речни- } \\
\text { ка ученика на појмовном и терминолошком нивоу; усвајање } \\
\text { лексике која се односи на математичке појмове; подстицање } \\
\text { ученика да разумеју, усвоје и примене стечена знања из ен- } \\
\text { глеског језика и математике у одговарајућим говорним и } \\
\text { практичним ситуацијама; }\end{array}$ \\
\hline $\begin{array}{l}\text { Практични } \\
\text { циљеви }\end{array}$ & $\begin{array}{l}\text { припремање ученика за даље учење и за живот; повезивање } \\
\text { сазнајних и логичких радњи; приступање језику на лексич- } \\
\text { ки а не само на граматички начин; побољшавање општих и } \\
\text { специфичних језичких компетенција; повећавање мотивације } \\
\text { ученика; повезивање знања из два предмета; препознавање } \\
\text { значења непознатих речи и израза на основу контекстау коме } \\
\text { су употребљени; припремање ученика за примену стеченог } \\
\text { знања у решавању истраживачких и проблемских задатака; } \\
\text { развијање ученичке самосталности у раду; развијање моћи } \\
\text { закључивања; припрема ученика за двојезичну наставу што, } \\
\text { на дужи рок, појачава друштвено профилисање школе }\end{array}$ \\
\hline $\begin{array}{l}\text { Васпитни } \\
\text { циљеви }\end{array}$ & $\begin{array}{l}\text { увођење ширег културног контекста и повећање освешће- } \\
\text { ности о нешколском коришћењу језика; интернационали- } \\
\text { зација наставе; припремање ученика за даље учење на ен- } \\
\text { глеском језику; развијање интересовања за мултилингвално } \\
\text { учење код ученика; подстицање ученичке радозналости }\end{array}$ \\
\hline Облици рада & фронтални, индивидуални \\
\hline $\begin{array}{l}\text { Наставне } \\
\text { методе }\end{array}$ & $\begin{array}{l}\text { - CLIL - Content and Language Integrated Learning } \\
\text { - интерактивна метода } \\
\text { - метода разговора (дијалошка) } \\
\text { - метода размене мишљења } \\
\text { - метода активне наставе } \\
\text { - демонстративно-илустративна метода } \\
\text { - корелативна метода }\end{array}$ \\
\hline Место рада & учионица \\
\hline $\begin{array}{l}\text { Наставна } \\
\text { средства и } \\
\text { потребан } \\
\text { материјал }\end{array}$ & пројектор, лаптоп, припремљени материјал \\
\hline $\begin{array}{l}\text { Активности } \\
\text { ученика }\end{array}$ & $\begin{array}{l}\text { - слушају и прате упутства наставника } \\
\text { - користе енглески језик током читавог часа } \\
\text { - учествују у разговору са наставником } \\
\text { - слушају ученика који ради задатак } \\
\text { - износе своје (евентуално) неслагање уз објашњење }\end{array}$ \\
\hline
\end{tabular}


ПРИМЕР ДОБРЕ НАСТАВНЕ ПРАКСЕ ...

\begin{tabular}{|c|c|}
\hline $\begin{array}{l}\text { Активности } \\
\text { наставника }\end{array}$ & $\begin{array}{l}\text { - организује процес рада у учионици } \\
\text { - разговара на енглеском током читавог часа, даје упутства, } \\
\text { усмерава, прати и мотивише ученике } \\
\text { - из другог плана координира активности у учиници и води } \\
\text { рачуна о временском оквиру } \\
\text { - поставља питања у вези са изведеном активношћу и } \\
\text { закључцма до којих се дошло, усмерава разговор ученика } \\
\text { и пружа потребну помоћ }\end{array}$ \\
\hline Резултати часа & $\begin{array}{l}\text { Ученик је у стању да препозна и користи лексику каракте- } \\
\text { ристичну за одређену науку, да разликује стручни текст од } \\
\text { информативног и књижевног и да користи енглески језик у } \\
\text { служби учења нејезичког садржаја }\end{array}$ \\
\hline Корелација & математика \\
\hline $\begin{array}{l}\text { Коришћена } \\
\text { литература }\end{array}$ & / \\
\hline \multicolumn{2}{|l|}{ Ток часа } \\
\hline $\begin{array}{l}\text { Претходна } \\
\text { припрема } \\
\text { ученика }\end{array}$ & Не врши се. \\
\hline $\begin{array}{l}\text { Уводни део часа } \\
\text { - око } 10 \text { минута }\end{array}$ & $\begin{array}{l}\text { Наставник подсећа ученике на тему о којој је било речи на } \\
\text { претходном часу - Science Matters. Нставник сужава тему } \\
\text { са прошлог часа на подтему Maths Matters, што је уједно и } \\
\text { наслов данашње лекције, који наставник записује на таблу. } \\
\text { Разговор на тему математике и њеног значаја се наставља } \\
\text { питањима: } \\
\text { Does maths matter? } \\
\text { Why is maths important? } \\
\text { Which other school subject is important for life? Why? } \\
\text { Imagine you could choose subjects to learn at school, which would } \\
\text { you choose? } \\
\text { What do you think about learning (the chosen subject) in English? } \\
\text { Could it be interesting? Why, what does it give to you? } \\
\text { What do you think about studying abroad? }\end{array}$ \\
\hline
\end{tabular}




\section{Ирена Пантић}

\begin{tabular}{|c|c|}
\hline $\begin{array}{l}\text { Главни део часа } \\
\text { - око } 30 \text { минута }\end{array}$ & 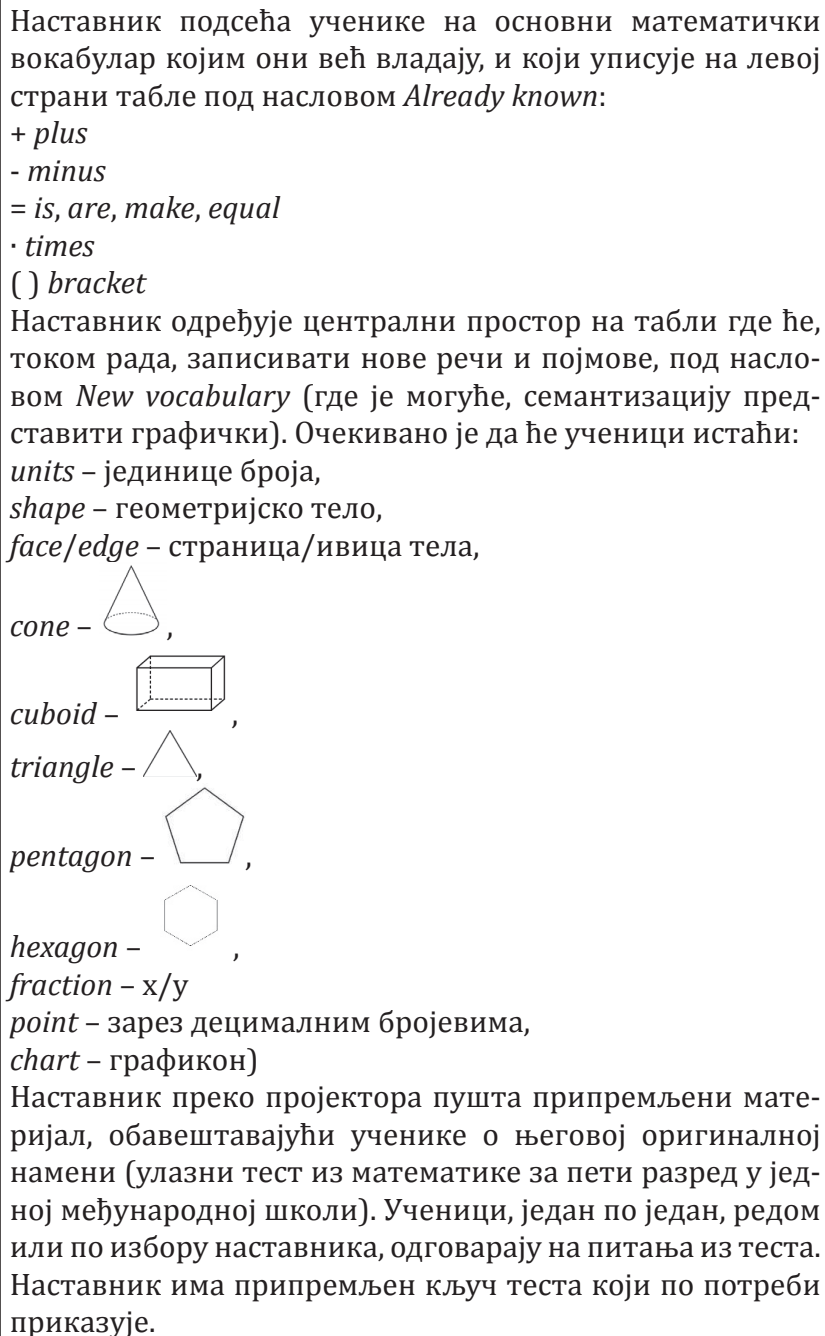 \\
\hline
\end{tabular}


ПРИМЕР ДОБРЕ НАСТАВНЕ ПРАКСЕ ...

\begin{tabular}{|c|c|}
\hline $\begin{array}{l}\text { Завршни део } \\
\text { часа } \\
\text { - око } 10 \text { минута }\end{array}$ & $\begin{array}{l}\text { Наставник уводи ученике у разговор на тему управо } \\
\text { рађеног задатка. Разговор је уједно и ученичка евалуација } \\
\text { часа. } \\
\text { 1. How do you like this English Maths? } \\
\text { 2. Was it interesting? Why? } \\
\text { 3. Is it important / useful? Why? } \\
\text { 4. Were you surprised with something (vocabulary, difficulty, } \\
\text { approach....)? } \\
\text { 5. Have you learnt anything new? What? } \\
\text { 6. Which other subject would you like to try in English? } \\
\text { 7. Any questions / comments? }\end{array}$ \\
\hline Напомена & $\begin{array}{l}\text { Очекивано је да } 30 \text { минута буде довољно да се пређе цео } \\
\text { тест. Уколико не буде довољно времена наставник ће } \\
\text { прекинути рад по истеку } 30 \text { минута да би остало времена } \\
\text { за планирану завршницу часа са евалуацијм (разговор са } \\
\text { ученицима). }\end{array}$ \\
\hline Домаћи задатак & 1 \\
\hline $\begin{array}{l}\text { Прилагођавање } \\
\text { наставе или рад } \\
\text { по ИоП }\end{array}$ & / \\
\hline $\begin{array}{l}\text { Самоевалуација } \\
\text { часа }\end{array}$ & $\begin{array}{l}\text { Параметри на основу којих би се вршила самоевалуација } \\
\text { часа су следећи: } \\
\text { - ангажовање и учествовање свих ученика у раду } \\
\text { - одржавање пажње и интересовања ученика током чи- } \\
\text { тавог часа } \\
\text { - праћење задатог временског оквира } \\
\text { - стварање атмосфере која ученике мотивише на учество- } \\
\text { вање }\end{array}$ \\
\hline Прилози & $\begin{array}{l}\text { Штампани или електронски примерак теста за пети раз- } \\
\text { ред школе The English Academy, Kuwait www.tea.edu.kw }\end{array}$ \\
\hline
\end{tabular}




\section{The ENGLISH Academy}

\section{Primary Department} Entrance Exam - Maths

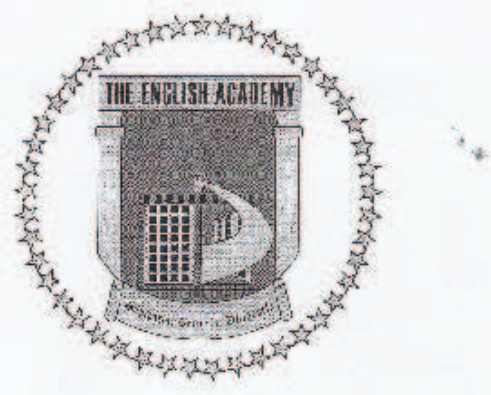

\section{Entrance into Year 5}

NAME

CURRENT SCHOOL

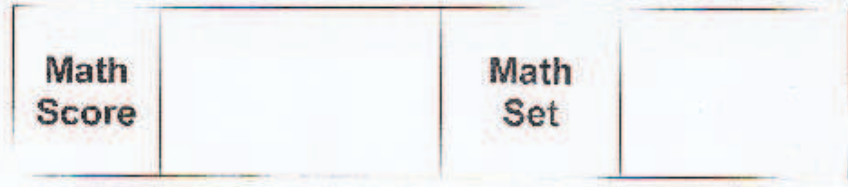




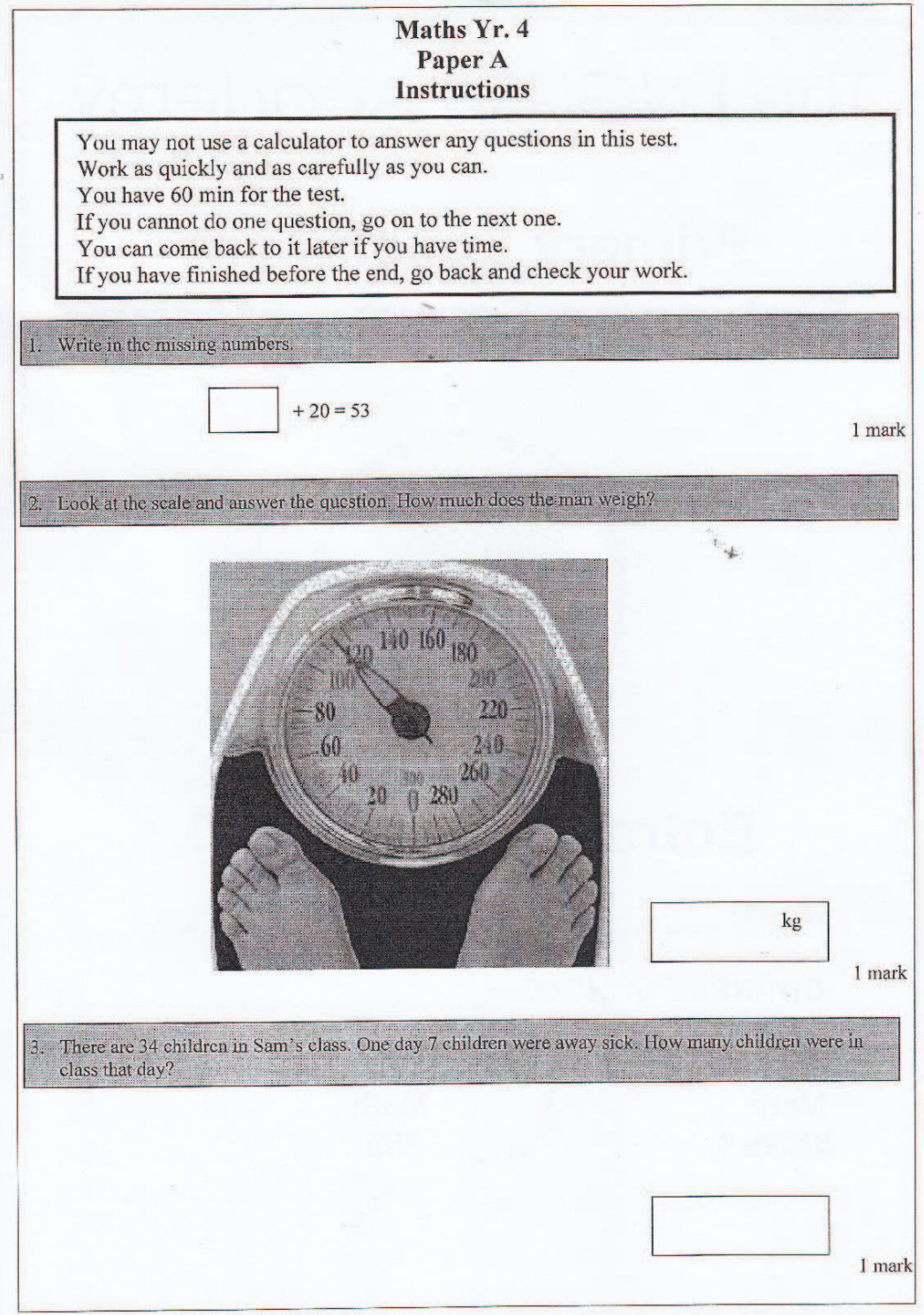


Ирена Пантић

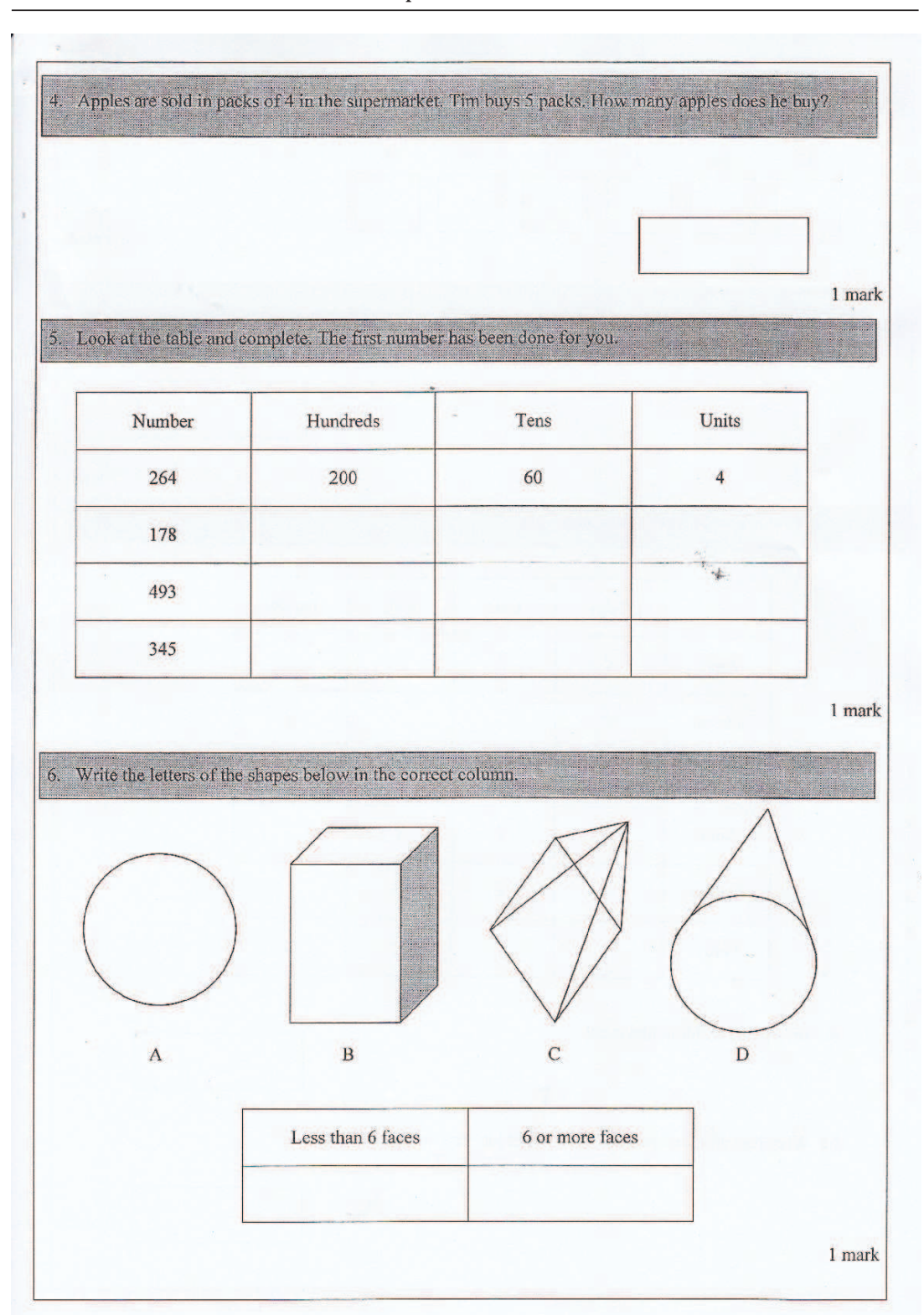


ПРИМЕР ДОБРЕ НАСТАВНЕ ПРАКСЕ ...

\begin{tabular}{|l|l|c|c|c|c|}
\hline 7. Order these numbers fiom smallest to largest. \\
\hline 8. Thave 2 edges and 3 faces. What shape am 1? \\
\hline \\
\hline
\end{tabular}


Ирена Пантић

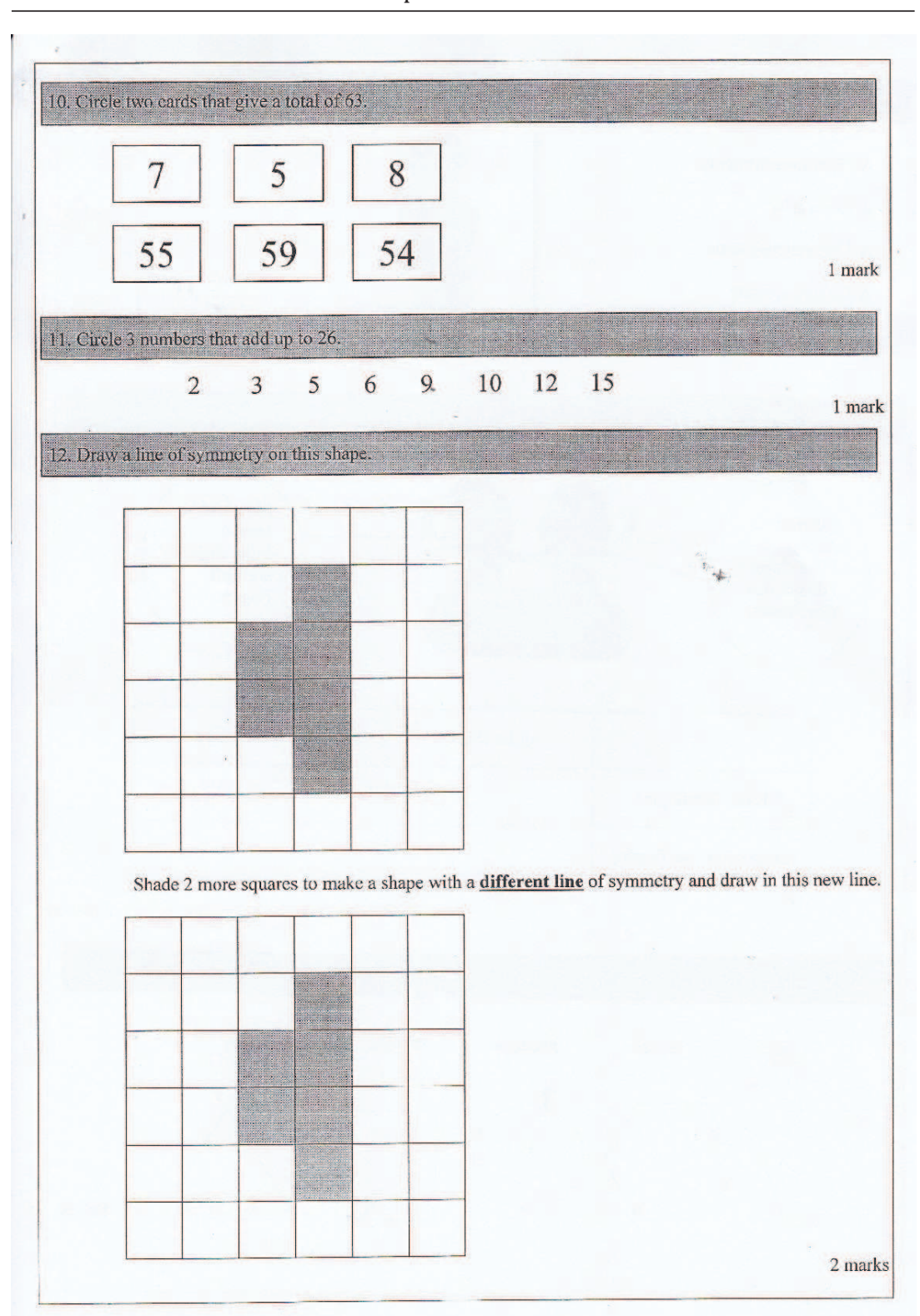




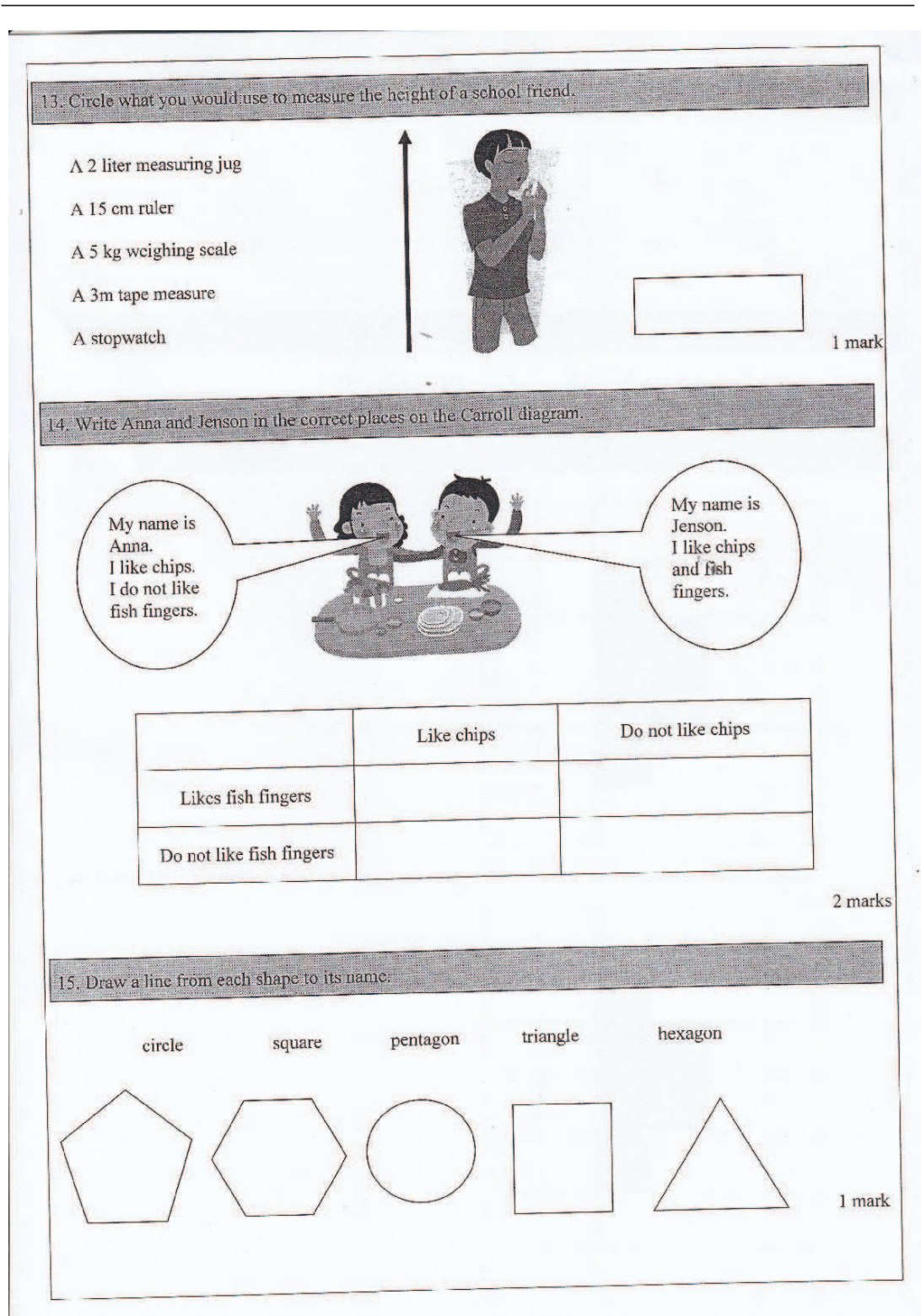


Ирена Пантић

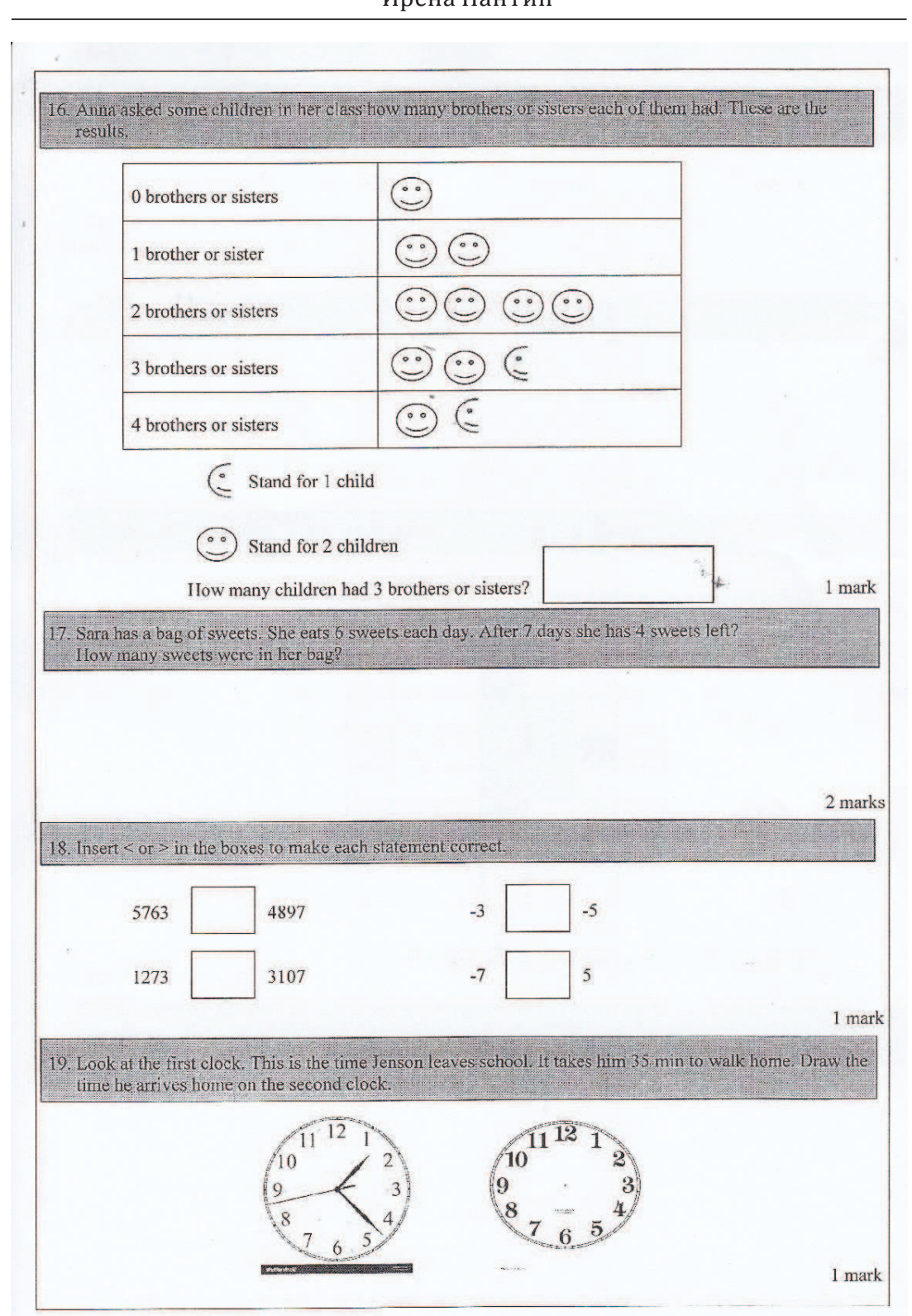


ПРИМЕР ДОБРЕ НАСТАВНЕ ПРАКСЕ ...

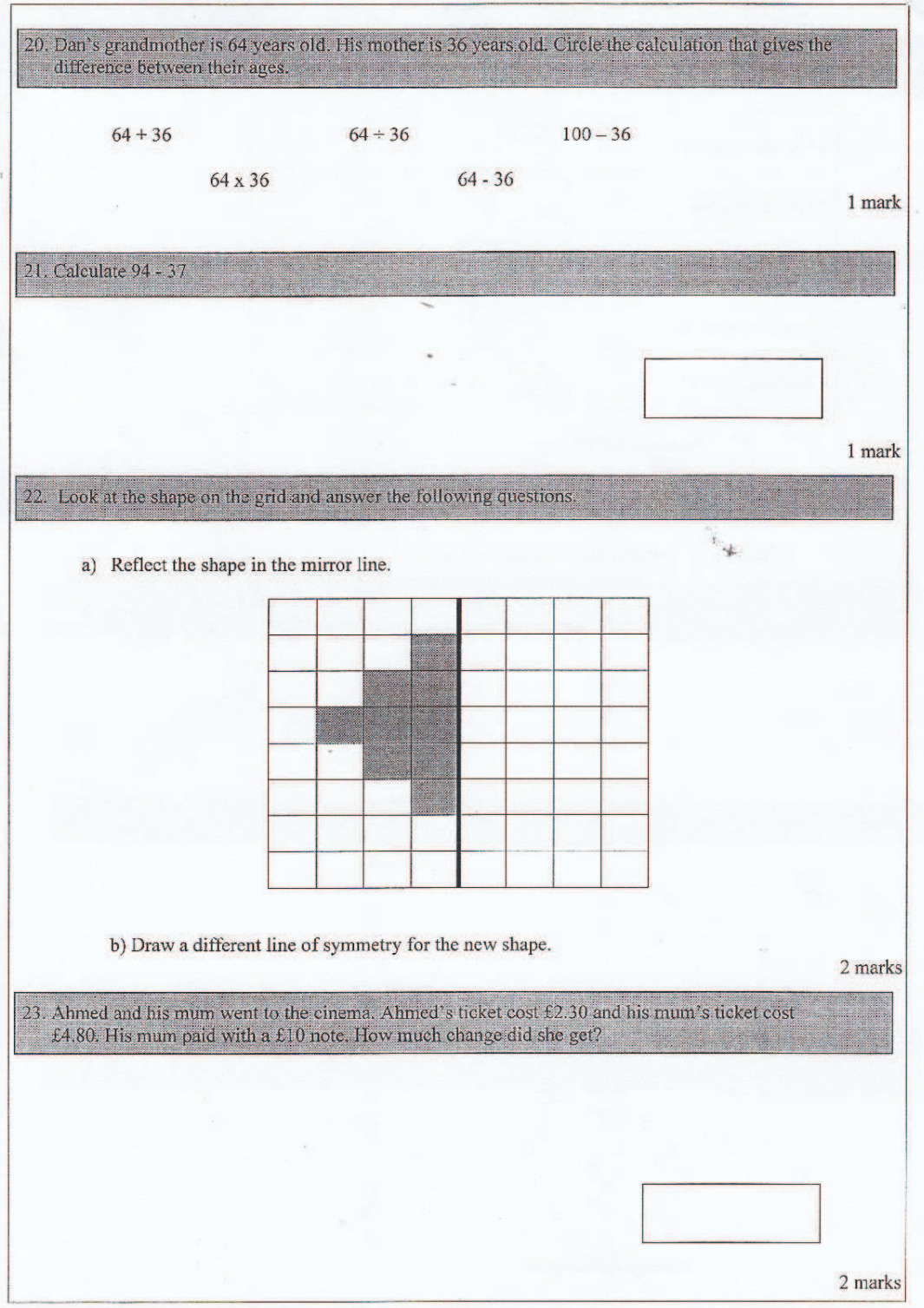


Ирена Пантић

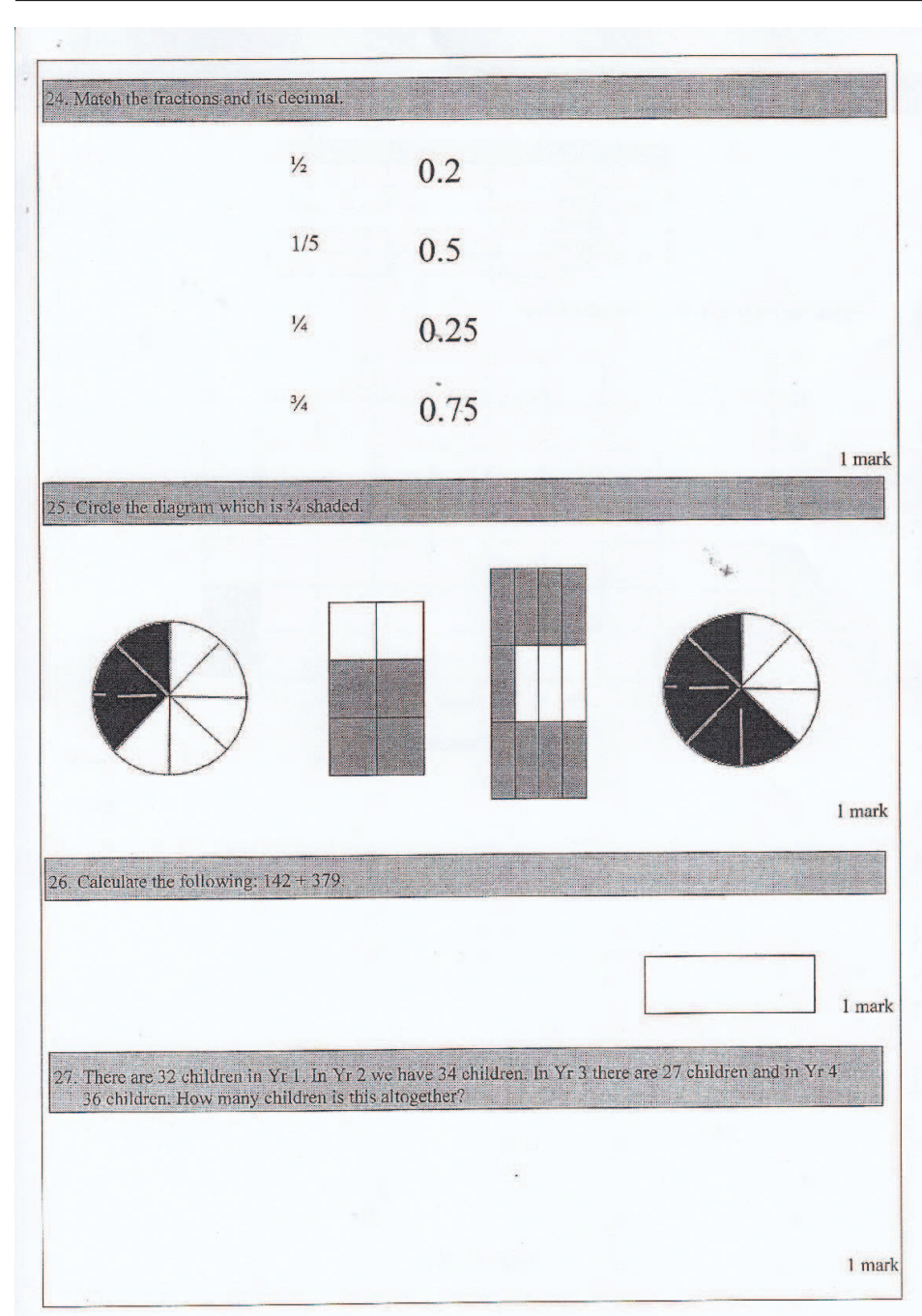


ПРИМЕР ДОБРЕ НАСТАВНЕ ПРАКСЕ ...

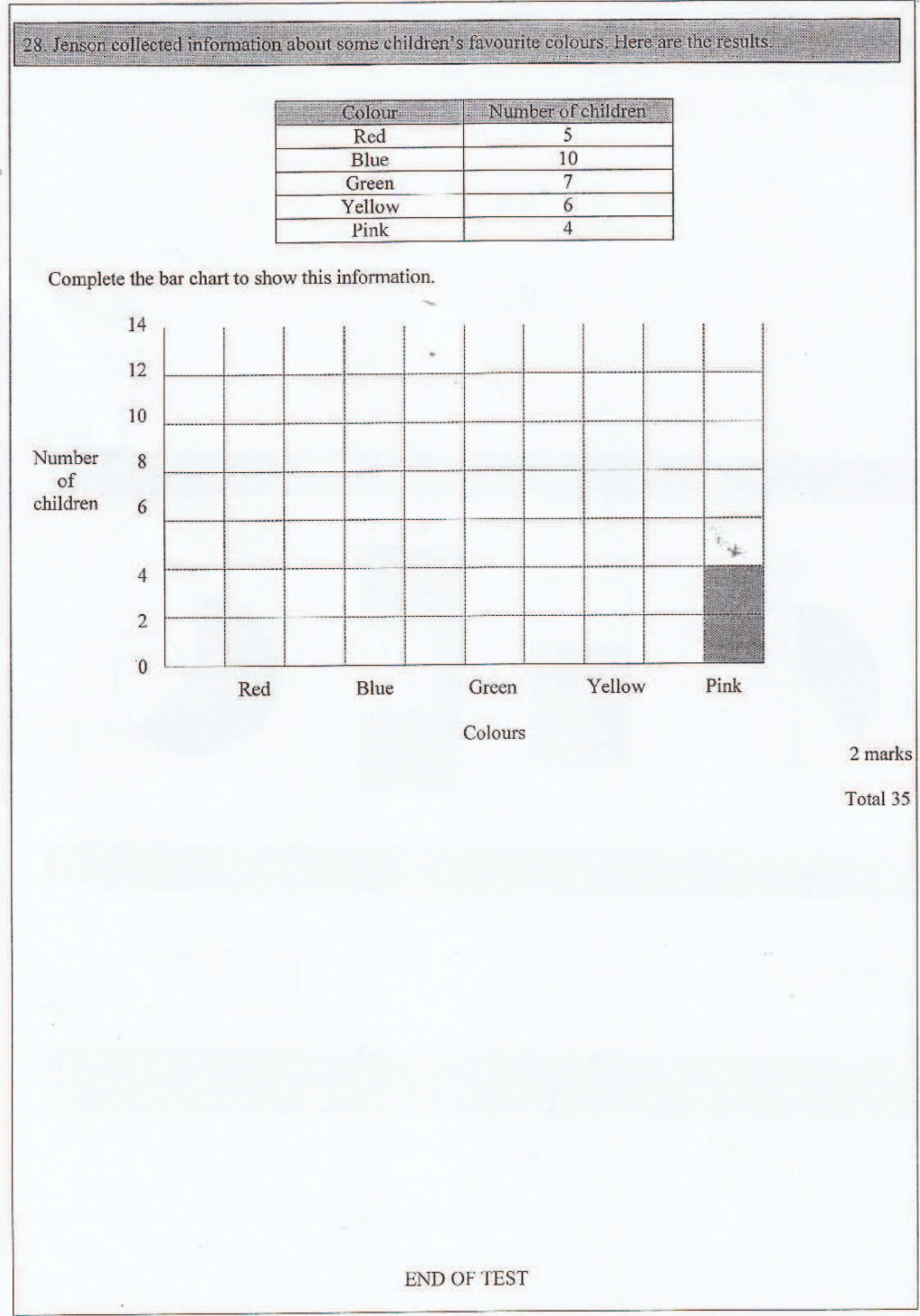


Ирена Пантић

\title{
Irena Pantić
}

\section{AN EXAMPLE OF GOOD TEACHING PRACTICE - TEACHING ENGLISH THROUGH THE CLIL METHOD}

\begin{abstract}
Summary
Organisation of an English lesson through CLIL methodology helped students practise some non-language content, and acquire its specific terminology in English. Here, it was a basic mathematical content. Students were able to improve and advance their existing knowledge of arithmetic operations through issues that they cannot obtain in traditional English classes - names of geometric shapes (circle, square, pentagon, triangle and hexagon), objects (sphere, cuboid, pyramid, cone), decimals and fractions.

In such a lesson, English was used as a mediator language, and its focus was not upon grammar but upon vocabulary acquisition and communication. In that way, Content and Language Integrated Learning (CLIL), although still an innovative strategy, represents a very good framework for facilitating an effective acquisition of contents from a specific subject curriculum. Its cross-curricular structure develops the communication in a foreign language, as well.

Pupils' pleasure and enthusiasm, high learning motivation, developed their self-confidence while speaking in the foreign language and higher exposure to the language made this lesson a success.

Introducing CLIL methodology into regular classes, even at primary schools, branches out into bilingual education at our schools. In the long term, it enables pupils develop their language competences effectively, widen multilingualism and interculturality, and prepare for future schooling (maybe abroad) and career.
\end{abstract}

